\title{
Growth Performance, Blood Profile, and Carcass Characteristics of Weaned Pigs Fed Low Crude Protein Diets Supplemented with Lysine
}

\author{
T. K. Ojedirana, E. O. Babatunde ${ }^{a}$, S. O. Olokun , , O. K. Adigun ${ }^{a}$, B. B. Ajao ${ }^{a}$, F. Emaye ${ }^{a}$, M. D. Shittu ${ }^{a}$, \& \\ F. A. Adejoro ${ }^{\mathrm{b}, *}$ \\ aDepartment of Animal Nutrition and Biotechnology, Ladoke Akintola University of Technology, \\ Ogbomoso, Nigeria \\ bDepartment of Agriculture, Faculty of Natural Sciences, Mangosuthu University of Technology, \\ P.O. Box 12363, Jacobs, 4026, Durban, South Africa \\ *Corresponding author: adejoro.festus@mut.ac.za \\ (Received 03-03-2021; Revised 21-4-2021; Accepted 03-05-2021)
}

\begin{abstract}
Supplementing low crude protein (CP) diets for pigs with exogenous amino acid may help improve growth performance, minimize the environmental impact associated with nitrogen loss and improve the sustainability of pork production. A total number of thirty (30) Large white $x$ Landrace weaned pigs between the age of 8-10 weeks and an average weight of $11.5 \pm 0.39 \mathrm{~kg}$ were used to evaluate the effect of lysine supplementation of a low CP diet on growth performance, blood profile, and carcass characteristics of weaner piglets. Weaned pigs were acclimatized for seven days, randomly allotted to five (5) dietary treatments with six weaners per treatment and fed a weaner diet based on maize-soybean while wheat bran and dried cassava peel were added to balance the diet nutrients. The animals were allocated to either a control diet containing $22.6 \% \mathrm{CP}$ or a diet with $2.5 \%, 5.0 \%, 7.5 \%$, and $10 \%$ reduction in diet CP. Each animal consumed the respective diet for six weeks during which growth performance was monitored. Afterward, $5 \mathrm{~mL}$ of blood was sampled for analysis, and all the pigs were slaughtered for carcass analysis. Average daily gain, total weight gain, and average daily intake were not significantly different across the groups ( $p>0.05)$. While feed cost per $\mathrm{kg}$ was lower with the $7.5 \%$ and $10 \%$ diet $C P$ reduction $(p<0.05)$, feed cost per weight gain was not different across the animals. Most haematological and serum biochemical variables were not affected by $\mathrm{CP}$ reduction, while carcass weight was equally not affected by diet CP $(\mathrm{p}>0.05)$. However, the abdominal fat percentage of carcass reduced slightly with the reduced diet $\mathrm{CP}$. Therefore, up to $10 \%$ reduction in diet $\mathrm{CP}$ from $22.6 \%$, with $0.1 \%$ lysine supplementation, had no negative impact on growth without compromising the immunity indicators of weaned pigs. Furthermore, there was no negative consequence on carcass characteristics and the primal cuts.
\end{abstract}

Keywords: lysine; crude protein; feed cost; growth performance; meat quality

\section{INTRODUCTION}

Interest in alternative feeding strategies which are cost-effective and environmentally friendly with consistent pork quality is of mutual interest to farmers, environmentalists, researchers, and consumers. One of such strategies is the use of low crude protein diets (Toledo et al., 2014). Farmers want to stay in business, increase profit by reducing the cost of production and low CP diets afford them that opportunity (Wang et al., 2018). Reducing the environmental footprint of pork production can be achieved through a significant reduction in fecal and urine nitrogen losses by reducing diet CP (Toledo et al., 2014). When the AA requirement of the animal is met, excess dietary protein results in higher urea nitrogen excretion in the blood and consequently in urine (Zhang et al., 2016). Aside from the nutrient loss, the excretion of excess nitrogenous wastes from pig production increases odor emission from pig production units (Sajeev et al., 2018; Wang et al., 2018).

Furthermore, diet crude protein could affect carcass characteristics and meat quality that eventually influence consumer preferences (Suárez-Belloch et al., 2016). Crude protein restriction resulted in reduced hardness but increased intra-muscular fat (IMF) in finishing pigs which are desirable for dry-cured products (Grunert et al. 2004) although, Kumar (2021) noted that most consumers consider fat in meat is unhealthy. Nevertheless, Zhou et al. (2015) and Suárez-Belloch et al. (2016) demonstrated that intramuscular fat and carcass dressing percentage are not affected by the reduced dietary $\mathrm{CP}$. Furthermore, Morazán et al. (2015) observed the increased back-fat thickness and reduced loin muscle area in grower and finisher pigs with lower diet CP.

The NRC (2012) nutrient standards showed that lower $\mathrm{CP}$ diets, with the addition of synthetic AA, 
especially the first four limiting AAs (L-Lysine, DLmethionine, L-threonine, and L-tryptophan) could improve nitrogen utilization by reducing nitrogen excretion, lower feed cost, and promote intestinal health without compromising pig growth response (Fan et al., 2017). Lysine is the first limiting AA for young pigs who utilize them for body protein synthesis (Kahindi et al., 2017). The availability of synthetic AAs has provided the opportunity to reduce diet $\mathrm{CP}$ in growing pigs and meet their AA requirement through exogenous AA supplementation.

Despite the standards set by the NRC (2012), which are based on prediction models, there could arise wide variations in animal requirement as a result of breed differences, housing, and management conditions and therefore necessitating scenario-specific evaluations (Zhang et al., 2013; Kahindi et al., 2017). Only limited studies were carried out under tropical rearing conditions that evaluated AA supplementation under varying diet crude protein regimes. Furthermore, the cost of synthetic AA supplementation juxtaposed with reduced diet crude protein (Kahindi et al., 2017; Wang et al., 2018). However, the extent to which diet CP can be reduced with lysine supplementation needs to be established in tropical housing conditions where pigs can be prone to additional heat stress, which often has a confounding impact on their nutritional physiology without compromising the growth performance of the piglet. Therefore, the objective of the current study was to evaluate the effect of a gradual reduction in diet crude protein, with exogenous lysine supplementation, on growth performance and carcass characteristics of piglets raised under warm humid tropical conditions.

\section{MATERIALS AND METHODS}

\section{Ethics Statements}

All procedures involving animal handling, management, and slaughtering were approved by the Animal and Research Ethics Committee of the Ladoke Akintola University of Technology with approval number: ANB/20/19/1132-19P.

\section{Experimental Animals, Management, and Dietary Treatment}

The experiment was carried out at the Piggery Unit of the University (Latitude, $8^{0} 08^{\prime} \mathrm{N}$; Longitude $4^{0} 15^{\prime} \mathrm{E}$; Elevation, $347 \mathrm{~m})$. A total number of thirty (30) Large white $x$ Landrace male weaned piglets between the age of age 8-10 weeks and an average weight of $11.5 \pm 0.39$ $\mathrm{kg}$ were selected from the farm stock, adapted for seven days on a weaner feed before the commencement of the experiment. Piglets were weighed and randomly allotted to five (5) dietary treatments in a completely randomized design. Each piglet was housed individually in pens demarcated with iron mesh, and six replicate piglets were allocated to each treatment.

Piglets were offered a maize-soybean based diet with the control diet containing $22.6 \% \mathrm{CP}$ or alternative diets with $2.5 \%, 5 \%, 7.5 \%$, and $10 \%$ reduction in $\mathrm{CP}$, corresponding to $22.0 \%, 21.5 \%, 20.9 \%$, and $20.4 \% \mathrm{CP}$, respectively, while synthetic lysine $(0.1 \%$ inclusion $)$ was included across the diets (Table 1) to meet the $1.09 \%$ standard ileal digestible lysine for growing pigs gaining $600 \mathrm{~g}$ per day as recommended by Warnants et al. (2003).

\section{Data Collection}

Piglets were fed the respective diets in two daily installments at $07 \mathrm{~h} 00$ and $16 \mathrm{~h} 00$ and water was provided ad-libitum for 6 weeks. Feed offered and refusals were collected and weighed daily while the bodyweight of each piglet was taken every week. Thereafter, feed intake, average daily gain, and feed conversion ratio were calculated from body weight changes and feed consumption data (Adejoro et al., 2013). Feed cost per kg and the economic efficiency of growth were calculated as previously described (Ojediran et al., 2017).

At the end of the 6-week growth period, three piglets were randomly selected per treatment, corresponding to 15 piglets, and blood samples were collected via the jugular vein. A sample of blood was collected into sterilized bottles containing Ethylene Diamine Tetra-acetic Acid for the analysis of hematological parameters. A second blood sample was collected inside empty bottles to analyze serum biochemical parameters. Procedures for hematological analysis were as previously described (Ojediran et al., 2015). Alanine Transaminase (ALT), Aspartate Transaminase (AST), and Alanine phosphatase (ALP), Total serum protein, globulin, and albumin, total cholesterol, and triglycerides concentrations were analyzed using the Cobas Integra 400 Plus equipment.

All 30 pigs were stunned, slaughtered, and eviscerated using conventional slaughtering techniques and carcass characteristics expressed as bled weight, eviscer-

Table 1. Composition of the experimental diets

\begin{tabular}{|c|c|c|c|c|c|}
\hline Ingredient (\%) & $\begin{array}{l}\text { Control } \\
(\mathrm{T} 1)\end{array}$ & $\mathrm{T} 2$ & T3 & $\mathrm{T} 4$ & $\mathrm{~T} 5$ \\
\hline Maize & 51.2 & 51.2 & 51.2 & 51.1 & 49.5 \\
\hline Soybean meal & 29.0 & 29.0 & 29.0 & 29.0 & 28.0 \\
\hline Wheat offal & 13.9 & 9.20 & 4.61 & 0.00 & 0.00 \\
\hline Fish meal & 4.00 & 4.00 & 4.00 & 4.00 & 4.00 \\
\hline Cassava peel meal & 0.00 & 4.70 & 9.29 & 13.9 & 16.5 \\
\hline Limestone & 1.20 & 1.20 & 1.20 & 1.20 & 1.20 \\
\hline Lysine & 0.10 & 0.10 & 0.10 & 0.10 & 0.10 \\
\hline Salt & 0.50 & 0.50 & 0.50 & 0.50 & 0.50 \\
\hline${ }^{1}$ Premix & 0.20 & 0.20 & 0.20 & 0.20 & 0.20 \\
\hline Total & 100 & 100 & 100 & 100 & 100 \\
\hline \multicolumn{6}{|l|}{ Nutrient composition } \\
\hline Crude protein & 22.6 & 22.0 & 21.5 & 20.9 & 20.4 \\
\hline $\begin{array}{l}{ }^{2} \text { Metabolizable energy } \\
\text { (Kcal/kg) }\end{array}$ & 2881 & 2876 & 2872 & 2866 & 2707 \\
\hline${ }^{2}$ Lysine & 1.19 & 1.17 & 1.15 & 1.13 & 1.12 \\
\hline \multicolumn{6}{|c|}{$\begin{array}{l}\text { Note: }{ }^{1} \text { supplied the following (per } \mathrm{kg} \text { feed): vitamin A, } 12500 \mathrm{IU} \text {; vita- } \\
\text { min D3, } 5000 \mathrm{IU} \text {; vitamin E, } 40 \mathrm{mg} \text {; vitamin K3, } 2 \mathrm{mg} \text {; vitamin B1, } \\
3 \mathrm{mg} \text {; vitamin B2, } 5.5 \mathrm{mg} \text {; niacin, } 55 \mathrm{mg} \text {; calcium pantothenate, } \\
11.5 \mathrm{mg} \text {; vitamin B6, } 5 \mathrm{mg} \text {; vitamin B12, } 25 \mathrm{mg} \text {; folic acid, } 1 \mathrm{mg} \text {; } \\
\text { biotin, } 50 \mathrm{mg} \text {; choline chloride, } 500 \mathrm{mg} \text {; mangane }\urcorner \mathrm{se}, 300 \mathrm{mg} \text {; iron, } \\
120 \mathrm{mg} \text {; zinc, } 80 \mathrm{mg} \text {; copper, } 85 \mathrm{mg} \text {; iodine, } 1.5 \mathrm{mg} \text {; cobalt, } 3 \mathrm{mg} \text {; } \\
\text { selenium, } 1.2 \mathrm{mg} \text {; anti-oxidant, } 120 \mathrm{mg} \text {. }{ }^{2} \text { Calculated composition. }\end{array}$} \\
\hline
\end{tabular}


ated weight, carcass weight, jowl, boston butt, picnic shoulder, loin, spare rib, belly, ham trotters, and head.

\section{Data and Statistical Analysis}

All collected data were analyzed using the one-way analysis of variance technique of SAS (SAS Institute. Inc.: Cary, NC, USA,). Significantly different means among variables were separated using New Duncan's Multiple Range Test at $\mathrm{p}<0.05$.

\section{RESULTS}

The growth performances of the weaned pigs fed diets with varying CP levels with Lysine supplementation are shown in Table 2. Diet CP level did not affect total weight gain, average daily gain, average daily intake, and feed conversion ratio $(p>0.05)$. The average daily gain of the pigs ranged from 490-550 g/day. Reducing diet $\mathrm{CP}$ with exogenous lysine supplementation did not have any linear or quadratic effect on any growth or feed intake parameters ( $p>0.05)$.

Reducing diet crude protein from $22.6 \%$ to $20.9 \%$ (7.5\% reduction) and $20.4 \%$ (10\% reduction) resulted in significantly lower feed cost $(\mathrm{p}<0.05)$. However, feed cost per weight gain and efficiency of gain was not significantly different across the animals regardless of their $\operatorname{diet} \mathrm{CP}(\mathrm{p}>0.05)$ (Table 3).

The varying crude protein contents of diets with supplemental lysine did not affect most of the hematological parameters in weaner pigs $(\mathrm{p}>0.05)$ (Table 4$)$. Nevertheless, white blood cell counts and hematocrit concentration varied significantly across diet with different CP level $(p<0.05)$. Decreased diet CP resulted in increased WBC and hematocrit concentration. Results on serum biochemistry analysis showed that decreasing diet CP from 22.6 to 20.4 in weaner pigs with supplementary lysine did not affect Aspartate Transaminase (AST), Alkaline Transaminase (ALT), Alkaline Phosphate (ALP), Creatinine, Urea, Uric acid, Total Cholesterol (TCHO), Triglyceride (TAG), High-density lipoprotein, Total Protein, and Albumin concentration of the pigs ( $p>0.05)$ (Table 5). However, globulin concentration was higher when diet CP was reduced by $5 \%$ and $7.5 \%$ but only slightly higher when diet $\mathrm{CP}$ reduced by $2.5 \%$ and $10 \%$.

Table 6 shows the carcass characteristics and primal cuts of slaughtered pigs fed diet with different crude protein contents with added dietary lysine. The bled weight, eviscerated weight, buston butt, picnic shoulder, loin, spare rib, belly, ham, trotters, and head as a percentage of live weight were significantly influenced by diet CP $(\mathrm{p}<0.05)$. However, carcass weight and jowl $(p>0.05)$ were not affected. Reducing the diet CP by $2.5 \%$ from 22.6 resulted in significantly lower live weight at slaughter but bled weight was only affected at a $10 \%$ reduction in $\mathrm{CP}(20.4 \%$ diet $\mathrm{CP})$. Furthermore, the abdominal fat percentage was slightly lower with the reduced diet $\mathrm{CP}$.

\section{DISCUSSION}

Gloaguen et al. (2014) observed that in pig production, the need for dietary protein is a need for amino acids, which affects the growth response. The addition of the first limiting AA (L-lysine, DL-methionine, L-threonine, and L-tryptophan) to low crude protein diets had been established for an ideal dietary protein ratio. However, Wang et al. (2018) reported that discrepancies in growth response owing to the use of low

Table 2. Growth performance of weaned pigs fed diets with decreasing crude protein, and with lysine supplementation

\begin{tabular}{|c|c|c|c|c|c|c|c|c|c|}
\hline \multirow{2}{*}{ Variables } & \multicolumn{5}{|c|}{ Treatments } & \multirow{2}{*}{ SEM } & \multirow{2}{*}{ Treatment } & \multirow{2}{*}{ Lin } & \multirow{2}{*}{ Quad } \\
\hline & Control (T1) & $\mathrm{T} 2$ & T3 & $\mathrm{T} 4$ & T5 & & & & \\
\hline Initial weight (kg) & 11.4 & 11.4 & 11.5 & 11.6 & 11.7 & 0.39 & 0.99 & 0.84 & 0.97 \\
\hline Final weight (kg) & 34.5 & 34.4 & 32.7 & 32.2 & 33.3 & 0.86 & 0.93 & 0.53 & 0.66 \\
\hline Total weight gain $(\mathrm{kg})$ & 23.1 & 22.9 & 21.2 & 20.6 & 21.7 & 0.68 & 0.79 & 0.35 & 0.57 \\
\hline Average daily gain (g/d) & 550 & 546 & 504 & 491 & 516 & 16.2 & 0.76 & 0.35 & 0.57 \\
\hline Total feed intake (kg) & 50.8 & 50.3 & 51.1 & 50.7 & 50.0 & 1.85 & 1.00 & 0.94 & 0.93 \\
\hline Average daily intake (g/d) & 1209 & 1197 & 1216 & 1208 & 1189 & 44.0 & 1.00 & 0.94 & 0.93 \\
\hline Feed conversion ratio & 2.19 & 2.18 & 2.42 & 2.47 & 2.29 & 0.05 & 0.24 & 0.16 & 0.20 \\
\hline
\end{tabular}

Note: Diet includes control $(22.6 \%$ CP) or T2 $(22.0 \%)$, T3 $(21.5 \%)$, T4 $(20.9 \%) \&$ T5 $(20.4 \%)$ crude protein corresponding to $2.5 \%$, $5.0 \%$, $7.5 \%$, and $10 \%$ reduction, respectively. Treatment, effect of treatment; Lin, linear effect of diet CP; Quad, quadratic effect of diet CP.

Table 3. Economic indices of weaned pigs fed diets with decreasing crude protein, and with lysine supplementation

\begin{tabular}{|c|c|c|c|c|c|c|c|}
\hline \multirow{2}{*}{ Variables } & \multicolumn{5}{|c|}{ Treatments } & \multirow{2}{*}{ SEM } & \multirow{2}{*}{ P-value } \\
\hline & Control (T1) & $\mathrm{T} 2$ & $\mathrm{~T} 3$ & $\mathrm{~T} 4$ & T5 & & \\
\hline Feed Cost ( $\mathrm{A} / \mathrm{kg})$ & $125^{\mathrm{a}}$ & $123^{\mathrm{ab}}$ & $120^{\mathrm{abc}}$ & $118^{\mathrm{bc}}$ & $115^{c}$ & 0.02 & 0.02 \\
\hline Feed Cost/Weight gain ( $(/ \mathrm{kg})$ & 189 & 190 & 208 & 212 & 202 & 0.43 & 0.43 \\
\hline Economic efficiency of gain & 233 & 236 & 219 & 224 & 253 & 0.70 & 0.71 \\
\hline
\end{tabular}

Note: Nigerian Naira; SEM= standard error of mean. Diet includes control (22.6\% CP) or T2 (22.0\%), T3 (21.5), T4 (20.9\%) \& T5 (20.4\%) crude protein corresponding to $2.5 \%, 5.0 \%, 7.5 \%$, and $10 \%$ reduction, respectively. ${ }^{a, b, c}$ means in the same row with different superscripts differ significantly $(\mathrm{p}<0.05)$. 
Table 4. Hematological variables of weaned pigs fed diets with decreasing crude protein, and with lysine supplementation

\begin{tabular}{|c|c|c|c|c|c|c|c|}
\hline \multirow{2}{*}{ Variables } & \multicolumn{5}{|c|}{ Treatments } & \multirow{2}{*}{ SEM } & \multirow{2}{*}{ P-value } \\
\hline & Control (T1) & $\mathrm{T} 2$ & T3 & $\mathrm{T} 4$ & T5 & & \\
\hline White blood cell $\left(\times 10^{9} / \mu \mathrm{L}\right)$ & $3.45^{\mathrm{b}}$ & $6.40^{\mathrm{ab}}$ & $12.90^{\mathrm{a}}$ & $10.70^{\mathrm{ab}}$ & $7.70^{\mathrm{ab}}$ & 1.21 & 0.05 \\
\hline Red blood cell $\left(\times 10^{12} / \mu \mathrm{L}\right)$ & 4.56 & 6.11 & 7.76 & 4.14 & 7.55 & 0.62 & 0.21 \\
\hline Hematocrit (\%) & $30.5^{\mathrm{b}}$ & $42.3^{\mathrm{ab}}$ & $48.9^{\mathrm{ab}}$ & $29.4^{\mathrm{b}}$ & $54.6^{\mathrm{a}}$ & 3.78 & 0.01 \\
\hline Hemoglobin (g/dL) & 8.90 & 11.20 & 14.30 & 8.35 & 14.60 & 1.00 & 0.13 \\
\hline $\operatorname{MCV}(\mathrm{fl})$ & 73.9 & 71.6 & 64.0 & 74.5 & 73.1 & 1.86 & 0.41 \\
\hline $\mathrm{MCH}(\mathrm{pg})$ & 27.0 & 21.3 & 18.5 & 20.1 & 19.9 & 1.39 & 0.53 \\
\hline $\mathrm{MCHC}(\mathrm{g} / \mathrm{L})$ & 35.0 & 29.2 & 28.1 & 28.4 & 27.1 & 1.36 & 0.49 \\
\hline Lymphocytes (\%) & 41.4 & 41.9 & 61.0 & 35.6 & 55.0 & 4.97 & 0.52 \\
\hline Granulocyte (\%) & 44.3 & 40.6 & 31.8 & 54.3 & 38.3 & 3.94 & 0.5 \\
\hline RDW (\%) & 17.1 & 14.4 & 14.2 & 14.3 & 14.3 & 0.43 & 0.31 \\
\hline Platelets $\left(x 10^{9} / \mu \mathrm{L}\right)$ & 524 & 375 & 555 & 571 & 364 & 60.4 & 0.75 \\
\hline MPV (fl) & 12.90 & 8.92 & 9.08 & 11.48 & 10.05 & 0.75 & 0.54 \\
\hline PDW & 41.3 & 35.5 & 34.0 & 38.8 & 39.0 & 1.45 & 0.63 \\
\hline PCT (\%) & 0.63 & 0.35 & 0.54 & 0.64 & 0.37 & 0.08 & 0.67 \\
\hline
\end{tabular}

Note: $\mathrm{MCV}=$ mean corpuscular volume; $\mathrm{MCH}=$ mean corpuscular hemoglobin; $\mathrm{MCHC}=$ mean corpuscular hemoglobin concentration, $\mathrm{MPV}=$ mean platelet volume; PDW= platelet distribution width; PCT= platelet count. Diet includes control (22.6\% CP) or T2 (22.0\%), T3 (21.5), T4 (20.9\%) \& T5 $(20.4 \%)$ crude protein corresponding to $2.5 \%, 5.0 \%, 7.5 \%$, and $10 \%$ reduction, respectively. a,b,c means in the same row with different superscripts differ significantly $(\mathrm{p}<0.05)$.

Table 5. Serum biochemistry of weaned pigs fed diets with decreasing crude protein, and with lysine supplementation

\begin{tabular}{|c|c|c|c|c|c|c|c|}
\hline \multirow{2}{*}{ Variables } & \multicolumn{5}{|c|}{ Treatments } & \multirow{2}{*}{ SEM } & \multirow{2}{*}{ P-value } \\
\hline & Control (T1) & $\mathrm{T} 2$ & $\mathrm{~T} 3$ & $\mathrm{~T} 4$ & T5 & & \\
\hline AST (U/L) & 31.9 & 31.5 & 34.3 & 42.3 & 50.6 & 3.83 & 0.49 \\
\hline $\operatorname{ALT}(\mathrm{U} / \mathrm{L})$ & 18.6 & 17.5 & 20.2 & 21.7 & 22.8 & 1.50 & 0.84 \\
\hline $\operatorname{ALP}(\mathrm{U} / \mathrm{L})$ & 54.5 & 63.7 & 79.4 & 46.7 & 36.8 & 6.37 & 0.23 \\
\hline Creatinine $(\mu \mathrm{mol} / \mathrm{L})$ & 95.5 & 84.5 & 71.6 & 65.5 & 66.7 & 5.20 & 0.41 \\
\hline Urea $(\mu \mathrm{mol} / \mathrm{L})$ & 19.0 & 19.6 & 15.4 & 16.6 & 18.6 & 1.37 & 0.89 \\
\hline Uric acid (mg/dL) & 7.11 & 9.26 & 19.6 & 17.0 & 12.8 & 1.90 & 0.24 \\
\hline TCHO (mg/dL) & 127 & 115 & 124 & 123 & 118 & 7.00 & 0.99 \\
\hline Triglyceride (mg/dL) & 77.3 & 68.6 & 100 & 94.1 & 88.4 & 6.73 & 0.64 \\
\hline HDL (mg/dL) & 35.5 & 46.9 & 44.7 & 53.1 & 50.4 & 5.69 & 0.95 \\
\hline Total protein $(\mathrm{g} / \mathrm{L})$ & 4.81 & 6.88 & 8.42 & 8.42 & 8.14 & 0.52 & 0.20 \\
\hline Albumin (g/L) & 2.63 & 3.25 & 3.62 & 3.61 & 3.60 & 0.15 & 0.27 \\
\hline Globulin (g/L) & $2.18^{\mathrm{b}}$ & $3.63^{\mathrm{ab}}$ & $4.80^{\mathrm{a}}$ & $4.81^{\mathrm{a}}$ & $4.53^{\mathrm{ab}}$ & 0.37 & 0.02 \\
\hline
\end{tabular}

Note: AST= Aspartate Transaminase; ALT=Alkaline Transaminase; ALP=Alkaline Phosphate; TCHO= Total Cholesterol; TAG= Triglyceride. Diet includes control $(22.6 \% \mathrm{CP})$ or T2 $(22.0 \%)$, T3 (21.5), T4 (20.9\%) \& T5 (20.4\%) crude protein corresponding to $2.5 \%, 5.0 \%, 7.5 \%$, and $10 \%$ reduction, respectively. ${ }^{a, b, c}$ means in the same row with different superscripts differ significantly $(\mathrm{p}<0.05)$.

crude protein (LCP) diets might be attributed to $\mathrm{CP}$ levels used in relation to the control diet, feed ingredient type, the pattern of feeding (restricted or ad-libitum), and the experimental conditions. The lack of differences in growth response observed in the current study agrees with the report of Aquilani et al. (2019) on Cinta Senese pigs reared in a temperate environment. Similarly, A 3\% reduction in $\operatorname{diet} \mathrm{CP}$ with the exogenous supplementation of essential AA showed that growth performances of grower-finisher pigs were not affected (Prandini et al., 2013), but a reduction in growth response was observed by Roux et al. (2011). Consequently, Mansilla et al. (2017) noted that total nitrogen availability might be the reason for the declining growth response associated with reduced diet CP.
The use of LCP diets in pigs had been demonstrated to reduce the cost of feed (Wang et al., 2018), and although the current result validates this, feed cost per weight gain was not different across the treatments. Zhang et al. (2010) stated that in China, $10 \mathrm{~g} / \mathrm{kg}$ of diet $\mathrm{CP}$ reduction could translate to about a $1.50 \%$ decrease in feed cost. However, this decrease feed cost is subject to the other market forces like feed ingredient price, feed efficiency to weight gain, and premium price of the product. From this experiment, feed cost per weight gain and the economic efficiency of gain were not affected by diet $\mathrm{CP}$ reduction. This is contrary to the report of Ojediran et al. (2017) on broiler chickens.

The white blood cell count (WBC) and hematocrit concentrations increased as diet $\mathrm{CP}$ reduced although 
Table 6. Carcass characteristics and primal cuts of weaned pigs fed diets with decreasing crude protein, and with lysine supplementation

\begin{tabular}{|c|c|c|c|c|c|c|c|}
\hline \multirow{2}{*}{ Variables (\% liveweight) } & \multicolumn{5}{|c|}{ Treatments } & \multirow{2}{*}{ SEM } & \multirow{2}{*}{ P-value } \\
\hline & Control (T1) & $\mathrm{T} 2$ & T3 & $\mathrm{T} 4$ & T5 & & \\
\hline Bled Weight & $97.07^{a}$ & $96.31^{a}$ & $97.55^{a}$ & $97.49^{a}$ & $93.95^{b}$ & 0.38 & $<0.01$ \\
\hline Eviscerated Weight & $69.72^{b}$ & $70.20^{\mathrm{ab}}$ & $72.55^{\mathrm{a}}$ & $70.75^{\mathrm{ab}}$ & $71.45^{\mathrm{ab}}$ & 0.39 & 0.01 \\
\hline Carcass Weight & 59.44 & 59.2 & 59.03 & 58.97 & 58.47 & 0.41 & 0.97 \\
\hline Jowl & 1.51 & 1.38 & 2.39 & 3.06 & 2.9 & 0.28 & 0.16 \\
\hline Boston butt & $8.70^{\mathrm{b}}$ & $8.07^{b}$ & $11.50^{\mathrm{a}}$ & $9.36^{\mathrm{b}}$ & $9.35^{\mathrm{b}}$ & 0.38 & 0.02 \\
\hline Picnic Shoulder & $11.38^{\mathrm{b}}$ & $12.35^{\mathrm{ab}}$ & $10.63^{b}$ & $13.70 \mathrm{a}$ & $11.13^{\mathrm{b}}$ & 0.37 & 0.04 \\
\hline Loin & $11.94^{\mathrm{a}}$ & $10.34^{\mathrm{ab}}$ & $10.16^{\mathrm{b}}$ & $10.06^{\mathrm{b}}$ & $10.16^{\mathrm{b}}$ & 0.24 & 0.03 \\
\hline Sparerib & $3.91^{\mathrm{a}}$ & $3.64^{\mathrm{ab}}$ & $3.44^{\mathrm{b}}$ & $3.46^{\mathrm{b}}$ & $2.94^{c}$ & 0.1 & $<0.01$ \\
\hline Belly & $3.92^{\mathrm{b}}$ & $4.86^{\mathrm{a}}$ & $4.43^{\mathrm{a}}$ & $3.79^{\mathrm{b}}$ & $4.52^{\mathrm{a}}$ & 0.12 & $<0.01$ \\
\hline Ham & $16.86^{\mathrm{a}}$ & $15.57^{\mathrm{ab}}$ & $15.01^{\mathrm{b}}$ & $16.51^{\mathrm{a}}$ & $16.77^{a}$ & 0.25 & 0.04 \\
\hline Trotters & $0.02^{\mathrm{b}}$ & $0.02^{\mathrm{b}}$ & $0.03^{\mathrm{b}}$ & $0.50^{\mathrm{a}}$ & $0.03^{\mathrm{b}}$ & 0.003 & 0.01 \\
\hline Head & $9.16^{\mathrm{a}}$ & $8.36^{\mathrm{ab}}$ & $7.22^{c}$ & $7.47^{\mathrm{bc}}$ & $7.89^{\mathrm{bc}}$ & 0.22 & 0.01 \\
\hline Abdominal fat & $0.60^{a}$ & $0.51^{\mathrm{ab}}$ & $0.40^{\mathrm{ab}}$ & $0.48^{\mathrm{ab}}$ & $0.30^{\mathrm{b}}$ & 0.04 & 0.01 \\
\hline
\end{tabular}

Note: Diet includes control $(22.6 \%$ CP) or T2 (22.0\%), T3 (21.5), T4 (20.9\%) \& T5 (20.4\%) crude protein corresponding to $2.5 \%$, $5.0 \%$, $7.5 \%$, and $10 \%$ reduction, respectively. ${ }^{a, b, c}$ means in the same row with different superscripts differ significantly $(\mathrm{p}<0.05)$.

the data was characterized by a wide variability due to the smaller number of animals sampled for analysis. It is not clear if the marked increases in WBC values in diets T3-T5 are associated with the reduced diet CP because reduced blood iron profile can result in elevated WBC (Estienne et al., 2019). Both reduced iron and high WBC above the normal range are indicators of impaired immune function in animals. Bhattarai et al. (2015) observed a wide range of normal WBC values (8.7-37.9 $\times 10^{3}$ cells $/ \mu \mathrm{L}$ ) in weaner pigs under experimental conditions. Nevertheless, Kim et al. (2007) proved that LCP diets with adequate AA have the same biological effects on protein synthesis and the immunological defense of weaned pigs as higher CP diets. Van der Meer et al. (2017) reported that pigs fed LCP diets supplemented with AA under stress could modify immune status and improve the resistance to subclinical and clinical diseases. However, lysine deficiency would not directly affect the host immune response but would limit the synthesis of proteins (including cytokines) and the proliferation of lymphocytes (Peng et al., 2016). Lysine inclusion in this study may have helped sustain the concentration of immune indicators in the pigs receiving reduced $\mathrm{CP}$ since lysine could modulate the metabolism of arginine, a key amino acid linked with immune function (Peng et al., 2016). Hematocrit level reported in this study and the corpuscular parameters is the indications that the pigs were not in anemic condition (Oluwole and Omitogun, 2016).

The non-significant serum biochemistry parameters showed that the feeds were well tolerated and reduced CP did not affect the animal's physiology as noted by Zheng et al. (2016). This result is similar to the observation of Bindas et al. (2015). Serum urea nitrogen, the main nitrogenous end-product of protein catabolism (Zhang et al., 2016), is an indicator of reduced nitrogen excretion from blood to urine used as a measure of nitrogen released to the environment advantage of using LCP diets (Morales et al., 2015). Serum albumin will increase when protein intake exceeds the amount required for growth and maintenance. Cholesterol level is influenced by the type of feed consumed, while triglycerides are chains of high energy fatty acids necessary to provide energy for the cell to function. High levels of cholesterol and triglycerides have been associated with heart diseases (He et al., 2004). From this study, reducing diet $\mathrm{CP}$ did not have any deleterious effect on the liver and kidney function based on the concentration of the diagnostic markers such as AST, ALT, ALP and creatinine. These serum enzymes are very reliable indicators of liver and kidney function in animals (Ojediran et al., 2019).

Contrary to reports of some researchers (Figueroa et al., 2012; Wang et al., 2018) that pigs fed LCP diets had challenges of fatter carcasses, this study proves otherwise. However, while these authors focused on backfat thickness, the current study evaluated abdominal fat deposition in the growing pigs. Kerr et al. (2003) had noted the relationship between abdominal fat deposition and the availability of excess dietary energy in LP diets. The reason for the low fat-deposition in LCP diets compared to the pigs fed control diet in this study could be linked to the balance of amino acids, particularly the balance between lysine and branched-chain AA (L-leucine/ arginine) (Zhang et al., 2016). Balanced AA favors tissue protein synthesis compared to fat deposition because the metabolism of energy substrates is regulated through nitric oxide production (Rezaei et al., 2013; Liu et al., 2015). Previous studies on finishing pigs showed that decreasing diet $\mathrm{CP}$ with adequate lysine and proper AA balance resulted in lower fat deposition, whereas decreasing diet $\mathrm{CP}$ without balancing AA resulted in higher fat deposition (Wood et al., 2013). Furthermore, Wang et al. (2018) reported that an imbalance of energy to nitrogen might be the primary reason for the fatter carcass in pigs fed LCP diets which may be avoided by adopting the net energy system and balanced AA. 


\section{CONCLUSION}

Adequate lysine supplementation when diet $\mathrm{CP}$ is reduced by up to $10 \%$ had no negative impact on the growth performance of the growing pigs. Although feed cost was slightly lower at $7.5 \% \mathrm{CP}$ reduction, feed cost per $\mathrm{kg}$ weight gain was not significantly different across the animals. Equally, there was no negative impact on pig's hematological, serum biochemical, and carcass characteristics.

\section{CONFLICT OF INTEREST}

The authors declare that there is no conflict of interest with any financial, personal, or other relationships with other people or organization related to the material discussed in the manuscript.

\section{REFERENCES}

Adejoro, F. A., T. I. Ijadunola, O. M. Odetola, \& B. A. Omoniyi. 2013. Effect of sun-dried, soaked and cooked wild cocoyam (Colocasia esculenta) meal on the growth performance and carcass characteristics of broilers. Livest. Res. Rural Dev. 25: 1-7.

Aquilani, C., F. Sirtori, O. Franci, A. Acciaioli, R. Bozzi, A. Pezzati, \& C. Pugliese. 2019. Effects of protein restriction on performances and meat quality of cinta senese pig reared in an organic system. Animals 9: 310. https://doi. org/10.3390/ani9060310

Bhattarai, S. \& J.P. Nielson. 2015. Early indicators of iron deficiency in large piglets at weaning. J. Swine Health Prod. 23:10-17.

Bindas, L., I. Maskal'ova, \& L. Bujnak. 2015. The effect of protein metabolism on weanlings blood parameter level. Acta Fytotech Zootech. 18:76-78. https://doi.org/10.15414/ afz.2015.18.03.76-78

Estienne, M., S. Clark-Deener, \& K. Williams. 2019. Growth performance and hematology characteristics in pigs treated with iron at birth and weaning and fed a nursery diet supplemented with a pharmacological level of zinc oxide. J. Swine Health Prod. 27:64-75.

Fan, P., P. Liu, P. Song, X. Chen, \& X. Ma. 2017. Moderate dietary protein restriction alters the composition of gut microbiota and improves ileal barrier function in adult pig model. Sci Rep-Uk. 7:43412. https://doi.org/10.1038/ srep43412

Figueroa, J. L., J. Estrada, V. Zamora, J. L. Cordero, M. T. Sánchez-Torres, R. Nieto, \& J. M. F. Copado. 2012. Digestible lysine levels in low-protein diets supplemented with synthetic amino acids for nursery, growing, and finishing barrows. Irish J. Agr. Food Res. 33-44.

Gloaguen, M., N. Le Floc'H, E. Corrent, Y. Primot, \& J. van Milgen. 2014. The use of free amino acids allows formulating very low crude protein diets for piglets. J. Anim. Sci. 92:637-44. https://doi.org/10.2527/jas.2013-6514

Grunert, K.G., L. Bredahl, \& K. Brunsø. 2004. Consumer perception of meat quality and implications for product development in the meat sector-a review. Meat Sci. 66:259-72. https://doi.org/10.1016/S0309-1740(03)00130-X

He, Y., T. H. Lam, L. S. Li, S. F. He, \& B. O. Liang. 2004. Triglyceride and coronary heart disease mortality in a 24year follow-up study in Xi'am, China. Ann. Epid. 14: 1. https://doi.org/10.1016/S1047-2797(03)00069-3

Kahindi, R. K., J. K. Htoo, \& C. M. Nyachoti. 2017. Dietary lysine requirement for $7-16 \mathrm{~kg}$ pigs fed wheat-corn-soybean meal-based diets. J. Anim. Physiol. Anim. Nutr. (Berl). 101: 22-29. https://doi.org/10.1111/jpn.12491

Kerr, B. J., L. L. Southern, T. D. Bidner, K. G. Friesen, \& R. A. Easter. 2003. Influence of dietary protein level, amino acid supplementation, and dietary energy levels on growing-finishing pig performance and carcass composition. J. Anim. Sci. 81:3075-87. https://doi.org/10.2527/2003.81123075x

Kim, S.W., R. D. Mateo, Y. Yin, \& G. Wu. 2007. Functional amino acids and fatty acids for enhancing production performance of sows and piglets. Asian-Australas. J. Anim. Sci. 20:295-306. https://doi.org/10.5713/ajas.2007.295

Kumar, Y. 2021. Development of low-fat/reduced-fat processed meat products using fat replacers and analogues. Food Rev. Int. 37: 296-312. https://doi.org/10.1080/87559129.201 9.1704001

Liu Y., F. Li, L. He, B. Tan, J. Deng, X. Kong, Y. Li, M. Geng, Y. Yin, \& G. Wu. 2015. Dietary protein intake affects expression of genes for lipid metabolism in porcine skeletal muscle in a genotype-dependent manner. Brit. J. Nutr. 113:1069-77. https://doi.org/10.1017/S0007114514004310

Mansilla, W.D., J. K. Htoo, \& C. F. M. de Lange. 2017. Nitrogen from ammonia is as efficient as that from free amino acids or protein for improving growth performance of pigs fed diets deficient in nonessential amino acid nitrogen. J. Anim. Sci. 95:3093-102. https://doi.org/10.2527/jas.2016.0959

Morales, A., L. Buenabad, G. Castillo, N. Arce, B. A. Araiza, J. K. Htoo, \& M. Cervantes. 2015. Low protein amino acidsupplemented diets for growing pigs: effect on expression of amino acid transporters, serum concentration, performance, and carcass composition. J. Anim. Sci. 93:2154-64. https://doi.org/10.2527/jas.2014-8834

Morazán, H., J. Alvarez-Rodriguez, A. R. Seradj, J. Balcells, \& D. Babot. 2015. Trade-offs among growth performance, nutrient digestion and carcass traits when feeding low protein and/or high neutral-detergent fiber diets to growing finishing pigs. Anim Feed Sci Technol. 207:168-80. https://doi.org/10.1016/j.anifeedsci.2015.06.003

National Research Council (NRC). 2012. Nutrient requirements of swine. 11th Edn. Washington DC, USA: National Academy Press.

Ojediran, T. K., A. F. Ajayi, \& I. A. Emiola. 2019. Effects of processing methods and levels of inclusion of Jatropha curcas kernel meal on performance, organ characteristics, haematology and serum chemistry of finisher broiler chickens. J. Agric. Sci. 64: 69-83. https://doi.org/10.2298/JAS1901069O

Ojediran, T. K., T. B. Olayeni, M.D. Shittu, O. T. Ogunwemimo, \& I. A. Emiola. 2015. Residual Antinutrients in Differently Processed Jatropha Curcas Kernel Meals: Effect on Blood Parameters and Gut Microbes of Broiler Chicks. International J. Appl. Res. Technol. 4: 29-38. https://doi. org/10.5455/jasa.20141112084436

Ojediran, T.K., M. O. Fasola, T. O. Oladele, T. L. Onipede, \& I. A. Emiola. 2017. Growth perfor $\neg$ mance, flock uniformity and economic indices of broiler chickens fed low crude protein diets supplemented with lysine. Arch. de Zootec. 66: 543-550. https://doi.org/10.21071/az.v66i256.2770

Oluwole, O.O \& G. O. Omitogun. 2016. Haematological traits of Nigerian indigenous pig and its hybrid $(50 \%$ large white x 50 NIP) at post weaning ages. Am. J. Mol. Biol. 6:45-52. https://doi.org/10.4236/ajmb.2016.61005

Peng, X., L. Hu, Y. Liu, C. Yan, Z. F. Fang, Y. Lin, S. Y. Xu, J. Li, C. M. Wu, D. W. Chen, H. Sun, D. Wu, \& L.Q. Che. 2016. Effects of low-protein diets supplemented with indispensable amino acids on growth performance, intestinal morphology and immunological parameters in 13 to 35 kg pigs. Animal 10: 1812-1820. https://doi.org/10.1017/ S1751731116000999

Prandini, A., S. Sigolo, M. Morlacchini, E. Grilli, \& L. Fiorentini. 2013. Microencapsulated lysine and low-protein diets: 
effects on performance, carcass characteristics and nitrogen excretion in heavy growing-finishing pigs. J. Anim. Sci. 91: 4226-34. https://doi.org/10.2527/jas.2013-6412

Rezaei, R., W. Wang, Z. Wu, Z. Dai, J. Wang, \& G. Wu. 2013. Biochemical and physiological bases for utilization of dietary amino acids by young pigs. J. Anim. Sci. Biotechnol. 4: 1-12. https://doi.org/10.1186/2049-1891-4-7

Roux, M. L., A. L. Donsbough, A. M. Waguespack, S. Powell, T. D. Bidner, R. L. Payne, \& L. L. Southern. 2011. Maximizing the use of supplemental amino acids in corn-soybean meal diets for 20- to 45-kilogram pigs. J. Anim. Sci. 89:2415-24. https://doi.org/10.2527/jas.2010-3756

Sajeev, E. P. M., B. Amon, C. Ammon, W. Zollitsch, \& W. Winiwarter. 2018. Evaluating the potential of dietary crude protein manipulation in reducing ammonia emissions from cattle and pig manure: A meta-analysis. Nutr. Cycling Agroecosyst. 110: 161-175. https://doi.org/10.1007/ s10705-017-9893-3

Suárez-Belloch, J., M. A. Latorre, \& J. A. Guada. 2016. The effect of protein restriction during the growing period on carcass, meat and fat quality of heavy barrows and gilts. Meat Sci. 112:16-23. https://doi.org/10.1016/j.meatsci.2015.10.006

Toledo, J.B., A. C. Furlan, P. C. Pozza, J. Carraro, G. Moresco, S. L. Ferreira, \& A. G. Gallego. 2014. Reduction of the crude protein content of diets supplemented with essential amino acids for piglets weighing 15 to 30 kilograms. R. Bras. Zootec. 43:301-309. https://doi.org/10.1590/ S1516-35982014000600004

Van der Meer Y., A. Lammers, A. J. M. Jansman, M. M. J. A. Rijnen, W. H. Hendriks, \& W. J. J. Gerrits. 2016. Performance of pigs kept under different sanitary conditions affected by protein intake and amino acid supplementation. J. Anim. Sci. 94:4704-19. https://doi.org/10.2527/ jas.2016-0787

Wang, Y., J. Zhou, G. Wang, S. Cai, X. Zeng, \& S. Qiao. 2018. Advances in low-protein diets for swine. J. Anim. Sci. Biotechno. 9:60:1-14. https://doi.org/10.1186/ s40104-018-0276-7
Warnants, N., M. J. Van Oeckel, \& M. De Paepe. 2003. Response of growing pigs to different levels of ileal standardised digestible lysine using diets balanced in threonine, methionine and tryptophan. Livest. Prod. Sci. 82:201-209. https:// doi.org/10.1016/S0301-6226(03)00015-0

Wood, J. D., N.R. Lambe, G. A. Walling, H. Whitney, S. Jagger, P.J. Fullarton, J. Bayntun, K. Hallett, \& L. Bünger. 2013. Effects of low protein diets on pigs with a lean genotype. 1. Carcass composition measured by dissection and muscle fatty acid composition. Meat Sci. 95: 123-128. https://doi. org/10.1016/j.meatsci.2013.03.001

Zhang, G. J., C. Y. Xie, P. A. Thacker, J. K. Htoo, \& S. Y. Qiao. 2013. Estimation of the ideal ratio of standardized ileal digestible threonine to lysine for growing pigs $(22-50 \mathrm{~kg})$ fed low crude protein diets supplemented with crystalline amino acids. Anim. Feed Sci. Technol. 180:82-91. https:// doi.org/10.1016/j.anifeedsci.2013.01.006

Zhang, G., X. Yi, N. Lu, \& S. Qiao. 2010. Effects of low protein diet formulated by net energy system on growth performance and carcass characteristic of growing and finishing pigs. Chin. J. Anim. Nutr. 22:557-63.

Zhang, S., L. Chu, S. Qiao, X. Mao, \& X. Zeng. 2016. Effects of dietary leucine supplementation in low crude protein diets on performance, nitrogen balance, whole-body protein turnover, carcass characteristics and meat quality of finishing pigs. Anim. Sci. J. 87:911-20. https://doi.org/10.1111/ asj. 12520

Zheng, L., H. Wei, C. Cheng, Q. Xiang, J. Pang, \& J. Peng. 2016. Supplementation of branched-chain amino acids to a reduced-protein diet improves growth performance in piglets: involvement of increased feed intake and direct muscle growth-promoting effect. Brit. J. Nutr. 115:2236-45. https://doi.org/10.1017/S0007114516000842

Zhou, P., L. Zhang, J. Li, Y. Luo, B. Zhang, S. Xing, Y. Zhu, H. Sun, F. Gao, \& G. Zhou. 2015. Effects of dietary crude protein levels and cysteamine supplementation on protein synthetic and degradative signaling in skeletal muscle of finishing pigs. PloS One. 10:e139393. https://doi. org/10.1371/journal.pone.0139393 